\title{
Culturable bacteria associated with Anopheles darlingi and their paratransgenesis potential
}

\author{
Elerson Matos Rocha' ${ }^{1}$, Osvaldo Marinotti ${ }^{2}$, Deidre Machado Serrão ${ }^{3}$, Laura Viana Correa ${ }^{3}$, Ricardo de \\ Melo Katak', Juan Campos de Oliveira', Veranilce Alves Muniz ${ }^{3}$, Marta Rodrigues de Oliveira ${ }^{4}$, \\ Joaquim Ferreira do Nascimento Neto ${ }^{5}$, Marcos Cézar Fernandes Pessoa ${ }^{1}$, Rosemary Aparecida Roque ${ }^{5}$, \\ Adolfo Jose da Mota ${ }^{1}$, Piero Onorati ${ }^{6}$, Jayme A. Souza-Neto ${ }^{7}$, Olle Terenius ${ }^{6,8^{*}}$ (ID and Wanderli Pedro Tadei ${ }^{5^{*}}$
}

\begin{abstract}
Background: Malaria remains a major public health problem in South America, mostly in the Amazon region. Among newly proposed ways of controlling malaria transmission to humans, paratransgenesis is a promising alternative. Paratransgenesis aims to inhibit the development of parasites within the vector through the action of genetically modified bacteria. The first step towards successful paratransgenesis in the Amazon is the identification of Anopheles darlingi symbiotic bacteria, which are transmitted vertically among mosquitoes, and are not pathogenic to humans.

Methods: Culturable bacteria associated with An. darlingi and their breeding sites were isolated by conventional microbiological techniques. Isolated strains were transformed with a GFP expressing plasmid, pSPT-1-GFP, and reintroduced in mosquitoes by feeding. Their survival and persistence in the next generation was assessed by the isolation of fluorescent bacteria from eggs, larvae, pupae and adult homogenates.

Results: A total of 179 bacterial strains were isolated from samples from two locations, Coari and Manaus. The predominant genera identified in this study were Acinetobacter, Enterobacter, Klebsiella, Serratia, Bacillus, Elizabethkingia, Stenotrophomonas and Pantoea. Two isolated strains, Serratia-Adu40 and Pantoea-Ovo3, were successfully transformed with the PSPT-1-GFP plasmid and expressed GFP. The fluorescent bacteria fed to adult females were transferred to their eggs, which persisted in larvae and throughout metamorphosis, and were detected in adult mosquitoes of the next generation.
\end{abstract}

Conclusion: Serratia-Adu40 and Pantoea-Ovo3 are promising candidates for paratransgenesis in An. darlingi. Further research is needed to determine if these bacteria are vertically transferred in nature.

Keywords: Mosquito, Malaria, Microbiota, Vector-borne disease, Amazon forest

*Correspondence: olle.terenius@icm.uu.se; wptadei@gmail.com

${ }^{5}$ Laboratório de Malária E Dengue, Instituto Nacional de Pesquisas da Amazônia, INPA, Manaus, Brazil

${ }^{8}$ Department of Cell and Molecular Biology, Microbiology, Uppsala University, Box 596, 75124 Uppsala, Sweden

Full list of author information is available at the end of the article

\section{Background}

Malaria remains a major public health problem worldwide, with more than 200 million cases and nearly half a million deaths annually. Prompt diagnosis and treatment, preventive therapy and vector control are tools presently available to prevent malaria disease and death [1]. Despite substantial progress toward malaria control and elimination in the Americas, malaria has seen a

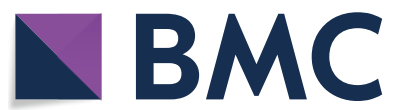

(c) The Author(s) 2021. This article is licensed under a Creative Commons Attribution 4.0 International License, which permits use, sharing, adaptation, distribution and reproduction in any medium or format, as long as you give appropriate credit to the original author(s) and the source, provide a link to the Creative Commons licence, and indicate if changes were made. The images or other third party material in this article are included in the article's Creative Commons licence, unless indicated otherwise in a credit line to the material. If material is not included in the article's Creative Commons licence and your intended use is not permitted by statutory regulation or exceeds the permitted use, you will need to obtain permission directly from the copyright holder. To view a copy of this licence, visit http://creativeco mmons.org/licenses/by/4.0/. The Creative Commons Public Domain Dedication waiver (http://creativecommons.org/publicdomain/ zero/1.0/) applies to the data made available in this article, unless otherwise stated in a credit line to the data. 
resurgence in the last years due to political unrest, worsening social and economic crisis and large-scale migration [2].

Anopheles darlingi is a major malaria vector in South America [1, 3, 4] and, therefore, a major target of vector control. Its importance as a malaria vector spurred studies of An. darlingi biology [5-7], behaviour [8, 9], physiology and biochemistry [10], genetics [11-13], and insecticide resistance [14, 15]. Because An. darlingi is anthropophilic, opportunistic, exophagic, and exophilic, long-lasting insecticidal nets and indoor residual spraying are not effective alone and novel vector control methods are needed to improve the control of malaria transmission by these mosquitoes [16-18]. For example, strategies deploying genetically-modified mosquitoes $[19,20]$ and their endosymbionts (paratransgenesis) [2124] have been proposed as vector-based tools for malaria control.

Paratransgenesis entails the colonization of mosquito gut with genetically engineered bacteria that are effective in inhibiting parasite development. Huang et al. [23] proposed that ideal endosymbionts for effective paratransgenesis application are easily manipulated genetically, colonize mosquitoes efficiently, spreading into mosquito populations (vertical and horizontal transmission), and are efficient in inhibiting pathogen development in mosquitoes. Proof-of-principle experiments such as those conducted by Yoshida et al. [25] and Wang et al. $[26,27]$ demonstrated that genetically modified bacteria are capable of interfering or blocking malaria parasite development in mosquitoes. Among the symbiotic bacteria found in malaria vectors, species belonging to the genera Asaia, Pantoea, Serratia, Pseudomonas and Thorsellia have been evaluated as candidates for paratransgenesis [28-30].

The microbial flora associated with An. darlingi has been investigated [31-36]. Here, in order to move forward toward paratransgenesis, symbiotic bacterial strains that are amenable to genetic manipulation, able to colonize $A n$. darlingi, and are transferred from adult females to their progeny were identified.

\section{Methods}

Field collection of Anopheles darlingi

Adults, pupae, and larvae of An. darlingi and water from their breeding sites were collected in Coari and Manaus (Table 1, Fig. 1). These are areas of active malaria
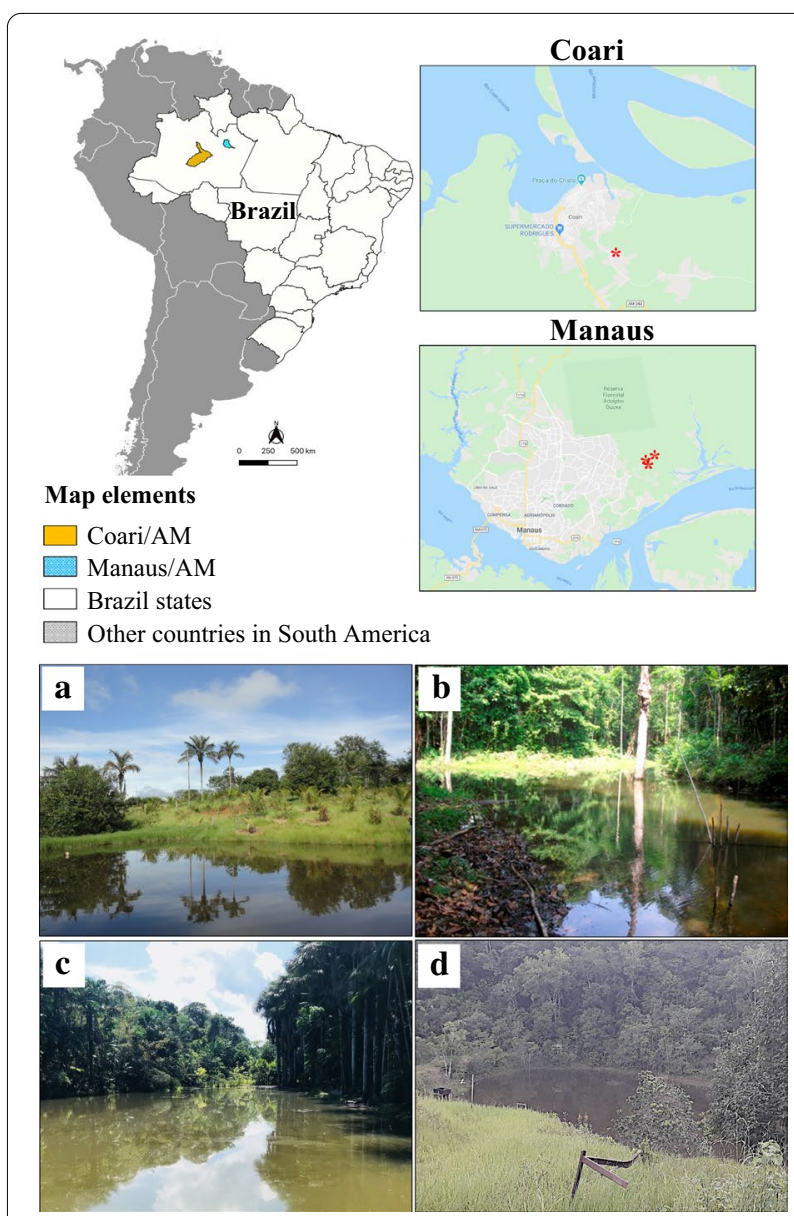

Fig. 1 Sample collection sites: Top-Maps of locations where samples were collected. Red dots indicate the locations where insects and water were collected Bottom-Pictures of collection sites. a Coari-Itapeuá -Sítio do Gordo $4^{\circ} 06^{\prime} 45.5^{\prime \prime} \mathrm{S}, 63^{\circ} 07^{\prime} 44.0^{\prime \prime} \mathrm{W}$; b Manaus, Puraquequara_Portela $3^{\circ} 02^{\prime} 47.0^{\prime \prime}$ S, 5952'54.4"W: c Manaus, Puraquequara-Dona Chagas 302'33.5"S, 59 $53^{\prime} 15.6^{\prime \prime} \mathrm{W}$ : d Manaus, Brasileirinho-Raifram 302'11.2"S, 5952'17.4"W

Table 1 Geographic location and characteristics of the Anopheles darlingi breeding sites where water, larvae and pupae were collected. Adults were captured in the same locations

\begin{tabular}{|c|c|c|c|}
\hline Local & Description & GPS coordinates & Date \\
\hline Coari-Itapeuá -Sítio do Gordo & Semirural/Dug ponds/ fish farming & $4^{\circ} 06^{\prime} 45.5^{\prime \prime} \mathrm{S}, 63^{\circ} 07^{\prime} 44.0^{\prime \prime} \mathrm{W}$ & $01 / 2014$ \\
\hline Manaus, Puraquequara_Portela & Semirural/Natural lake with small fish & $3^{\circ} 02^{\prime} 47.0^{\prime \prime} \mathrm{S}, 59^{\circ} 52^{\prime} 54.4^{\prime \prime} \mathrm{W}$ & $02 / 2017$ \\
\hline Manaus, Puraquequara-Dona Chagas & Semirural/Natural dam/fish farming & $3^{\circ} 02^{\prime} 33.5^{\prime \prime S}, 59^{\circ} 53^{\prime} 15.6^{\prime \prime} \mathrm{W}$ & $02 / 2018$ \\
\hline Manaus, Brasileirinho_-Raifram & Semirural/Private dam/ fish farming & $3^{\circ} 02^{\prime} 11.2^{\prime \prime S}, 59^{\circ} 52^{\prime} 17.4^{\prime \prime} \mathrm{W}$ & $02 / 2018$ \\
\hline
\end{tabular}


transmission, as determined by the Vigilância Epidemiológica da Secretaria Municipal de Saúde de Manaus (Epidemiological Surveillance of the Municipal Health Secretariat in Manaus). Mosquito collections were performed in a single site in each location, for three hours during dusk.

Surface microlayer (SML) water samples were collected using a stainless-steel mesh screen measuring $400 \mathrm{~cm}^{2}$, with a mesh size of $1.25 \times 0.36 \mathrm{~mm}$ wire diameter as described previously [37]. Water samples were transferred to sterile $50 \mathrm{ml}$ tubes and stored on ice.

Mosquito larvae and pupae were collected with a $350 \mathrm{ml}$ aluminum dipper, using standard dipping techniques [38]. Larvae and pupae were transferred to sterile plastic containers containing sterile water and stored on ice. Adult mosquitoes were collected during dusk in peri-domicile and extra-domicile environments. Adult females were captured by human landing catches (HLC), by trained technicians using personal protective equipment. Only non-blood fed females were selected for this study. Captured mosquitoes were transferred to $300 \mathrm{ml}$ wax-coated paper cups and transported to the laboratory. Water, larvae, pupae and adult mosquito samples were transported to the laboratory and processed within $24 \mathrm{~h}$. No mosquito mortality occurred during transportation. Species were identified using morphological characters [39].

Mosquito husbandry was at $29^{\circ} \mathrm{C}, 80 \%$ relative humidity and 12/12 light/dark cycles. Larvae were fed autoclaved fish food (Tetramin). Adults were given access to $10 \%$ sucrose solution ad libitum and fed on chicken blood when required for the experiments described below. All the protocols used in these studies received ethical clearance from the Brazilian National Institute for Amazonian Research (INPA) Ethics Committee and the biological material analyzed during the present study was collected with official collecting permission (17524-1 and 21264-5) given by 'Sistema de Autorização e Informação em Biodiversidade' (SISBIO) of the Brazilian Ministry of Environment (MMA).

\section{Bacteria isolation and morphological characterization}

Ten larvae, ten pupae and ten adults from each collection site were selected for bacterial isolation. Breeding water samples were plated directly from the transportation tubes, $50 \mu \mathrm{l}$ per Petri dish. Anopheles darlingi larvae (3rd and 4th instar), pupae, adult females and pools of 10 eggs were sequentially immersed five times, for a few seconds each time, in $70 \%$ ethanol and then deionized, autoclaved sterile water before being homogenized. Each larva, pupa, adult or eggs pool were individually homogenized in $1 \mathrm{ml}$ sterile water and centrifuged for $3 \mathrm{~min}$ at $8,000 \mathrm{rpm}$. The pellet was resuspended in $200 \mu \mathrm{l}$ of sterile water by vortexing and centrifuged again for $1 \mathrm{~min}$ at $800 \mathrm{rpm}$. From the supernatant, $50 \mu \mathrm{l}$ were plated in each Petri dish and spread with a Drigalski spatula. Bacteria extracted from all samples were plated on $90 \mathrm{~mm}$ Petri dishes containing Tryptic Soy Agar (TSA), Nutrient Agar (NA) or Luria-Bertani Agar (LB) medium. Fluconazole $(20 \mathrm{mg} / \mathrm{ml}$ ) was added to inhibit fungal growth.

Cultures were incubated at $29{ }^{\circ} \mathrm{C}$ for $24 \mathrm{~h}$. Negative control plates with only sterile water resulted in no colonies. The streak plate technique was applied for isolating specific bacteria from the original colonies potentially containing a mixture of microorganisms.

Colony morphology was inspected for size, shape, texture, elevation, and color. Additionally, cell type and Gram staining were examined for each isolate using standard microbiological techniques and a magnification microscope. Each isolate was preserved in $2 \mathrm{ml}$ cryotubes containing Nutrient Broth, $20 \%$ glycerol at $-80{ }^{\circ} \mathrm{C}$. Colonies displaying similar morphological and staining characteristics were assigned to groups and three representatives from each group were randomly selected for $16 \mathrm{~S}$ rRNA gene sequencing.

\section{DNA extraction, 16S rRNA gene amplification by PCR and sequence analyses}

DNA extraction, from isolated bacterial colonies, was performed with InstaGene ${ }^{\mathrm{TM}}$ Matrix (BioRad) following the manufacturer's instructions. DNA was spectrophotometrically quantified and adjusted to 150 nanograms/ $\mu$ l. Bacterial $16 \mathrm{~S}$ rRNA genes were amplified by PCR using Taq Pol-Master mix $2 \times$ (Cellco Biotec), and the primers 27F (5'-AGAGTTTGATCMTGGCTCAG-3') [40] and 1100R (5'-AGGGTTGCGCTCGTT-3') modified from Sawada et al. [41] used in a previous study [31]. Each reaction consisted of $12.5 \mu$ l Master mix; $1 \mu \mathrm{l}$ DNA (150 ng/ $\mu \mathrm{l}) ; 10.5 \mu \mathrm{l} \mathrm{H} \mathrm{H}_{2} \mathrm{O}$ milli-Q and $0.5 \mu \mathrm{l}(10 \mathrm{pMol})$ of each primer. The PCR program had an initial denaturation at $95^{\circ} \mathrm{C}$ for $3 \mathrm{~min}$, followed by 35 cycles of $\left[94^{\circ} \mathrm{C}\right.$ for $1 \mathrm{~min}, 54^{\circ} \mathrm{C}$ for $40 \mathrm{~s}, 72{ }^{\circ} \mathrm{C}$ for $90 \mathrm{~s}$ ], followed by a final extension at $72{ }^{\circ} \mathrm{C}$ for $5 \mathrm{~min}$. Amplicon production and size were verified by electrophoresis in a $0.8 \%$ agarose gel, stained with ethidium bromide. Amplicons were purified with PCR Purification Kit (Cellco Biotec), following the manufacturer's instructions and 200 ng of purified DNA was used for each sequencing reaction (BigDye Terminator V 3.1., Life Technologies and $10 \mathrm{pMol}$ of primer). $27 \mathrm{~F}$ and $1100 \mathrm{R}$ primers were used in separate sequencing reactions, generating data from both DNA strands.

Sequences were assembled using CAP3 program with the capability to clip $5^{\prime}$ and $3^{\prime}$ low-quality regions of reads, apply quality values in overlaps between reads, and generate consensus sequences [42]. Taxonomic assignments of the isolated bacteria were based on comparisons 
of the consensus sequence with $16 \mathrm{~S}$ sequences in GenBank applying BLASTn (https://blast.ncbi.nlm.nih.gov/ Blast.cgi) at the National Center for Biotechnology Information (NCBI) and the Ribosomal Database Project, RDP-II (http://rdp.cme.msu.edu/comparison/comp.jsp).

\section{Bacterial transformation}

Bacterial strains isolated in this study were grown in Nutrient broth. Electrocompetent cells were then prepared as described by Gonzales et al. [43] and transformed with the plasmid pSPT-1-GFP using an Electroporator 2510 (Eppendorf $^{\circledR}$ ). The plasmid pSPT-1-GFP (Additional file 1: Document S1) was kindly provided by Dr. Spartaco Astolfi Filho (CAM-UFAM). Following electroporation, bacteria were plated on Nutrient Agar containing $100 \mathrm{mg} / \mathrm{ml}$ ampicillin and incubated for $16 \mathrm{~h}$ at 37 ${ }^{\circ} \mathrm{C}$. Colonies expressing green fluorescent protein were identified by exposure to UV light, and were selected for further studies.

\section{Vertical transmission}

All experiments were conducted in three biological replicates. Wild $A n$. darlingi females were captured in Manaus, Raifram (Table 1) and transferred to the laboratory and kept without access to food and water for $12 \mathrm{~h}$. In each replica, 50 females were separated in three plastic cups (20, 20 and 10). The cup containing 10 mosquitoes (Control) was fed with cotton balls soaked in $10 \%$ sucrose for $6 \mathrm{~h}$. Sterile cotton balls soaked in 10\% sucrose containing $100 \mathrm{mg} / \mathrm{ml}$ ampicillin and $3 \times 10^{4} \mathrm{CFU} / \mathrm{ml}$ of GFP expressing bacteria (Serratia-Adu40 or PantoeaOvo3) were placed on the top of the mosquito cages containing 20 mosquitoes for $6 \mathrm{~h}$. Then, adult females were fed on chicken blood for $1 \mathrm{~h}$ and kept in the insectary until oviposition. Eggs were collected on moist sterile filter paper containing $100 \mathrm{mg} / \mathrm{ml}$ ampicillin.

The exterior of ten eggs from each female was surfacerinsed with $70 \%$ ethanol for $1 \mathrm{~min}$, then washed for $1 \mathrm{~min}$ in sterile distilled water. Surface-rinsed eggs were immediately homogenized and plated on Nutrient Agar plates with $100 \mathrm{mg} / \mathrm{ml}$ ampicillin. After oviposition, females were treated with $70 \%$ ethanol and sterile water, as described for the eggs. Their whole bodies were homogenized and plated on Nutrient Agar plates with $100 \mathrm{mg} /$ $\mathrm{ml}$ ampicillin. The remaining eggs were treated similarly for surface-rinsing with $70 \%$ ethanol and transferred to plastic containers filled with sterile deionized water containing $100 \mathrm{mg} / \mathrm{ml}$ ampicillin and food for development of the F1 generation. The containers were sterilized daily, water was discarded and replaced with fresh sterile water containing $100 \mathrm{mg} / \mathrm{ml}$ ampicillin and food. Ten larvae from each developmental instar (1st, 2nd, 3rd and 4th), 10 pupae and 10 three-day-old, sugar fed adults emerging from each family were rinsed with $70 \%$ ethanol and sterile water, as described above. Their whole bodies were homogenized and plated on Nutrient Agar plates with $100 \mathrm{mg} / \mathrm{ml}$ ampicillin. Bacterial colonies displaying GFP expression were identified by exposure to UV light after incubation for $16 \mathrm{~h}$ at $37^{\circ} \mathrm{C}$.

One set of experiments similar to that described above, but omitting ampicillin during the development of F1 mosquitoes, was performed to evaluate the effect of the antibiotic on the survival and persistence of GFP positive bacteria in An. darlingi.

\section{Results}

\section{Bacteria isolation and species identification}

A total of 900 bacterial colonies were included in this study, which were organized in 126 groups of morphologically similar colonies. Bacteria were isolated from $A n$. darlingi samples collected in two municipalities, Manaus and Coari, including larvae, pupae, adult females, their breeding site water and $A n$. darlingi eggs. There was no apparent difference in the number of colonies formed when plating breeding water and mosquito extracts in three growing media (TSA, NA and LB), therefore, Nutrient agar and Nutrient broth were used to isolate pure cultures and establish stable frozen stocks. Three representative isolates from 84 randomly selected groups were further characterized by $16 \mathrm{~S}$ rRNA gene PCR amplification and sequencing, resulting in 179 high quality sequences (Table 2).

Blastn with the 179 high-quality $16 \mathrm{~S}$ rRNA sequences revealed 35 genera of bacteria (Table 3). All sequences were registered in SisGen database (Sistema Nacional de Gestão do Patrimônio Genético e do Conhecimento Tradicional Associado) with the number A0F653E and are available in GenBank with accession numbers MT052372-MT052395 and MN709221-MN709375 (Additional file 1: Tables S1-S5).

Five genera from Proteobacteria (Achromobacter; Acinetobacter; Klebsiella; Serratia; and Siccibacter) and one Firmicutes genus (Bacillus) were identified

\begin{tabular}{|c|c|c|c|c|}
\hline & $\begin{array}{l}\text { Isolates } \\
\text { (purified } \\
\text { colonies) }\end{array}$ & $\begin{array}{l}\text { Groups (similar } \\
\text { morphological } \\
\text { characteristics) }\end{array}$ & $\begin{array}{l}\text { Groups } \\
\text { selected } \\
\text { for } 16 \mathrm{~S} \\
\text { sequencing } \\
\text { (random } \\
\text { selection) }\end{array}$ & $\begin{array}{l}\text { High } \\
\text { quality } 16 \mathrm{~S} \\
\text { sequences }\end{array}$ \\
\hline Manaus & 722 & 105 & 68 & 155 \\
\hline Coari & 178 & 21 & 16 & 24 \\
\hline Total & 900 & 126 & 84 & 179 \\
\hline
\end{tabular}


Table 3 Bacteria isolated from Anopheles darlingi and natural breeding water

\begin{tabular}{|c|c|c|c|c|c|}
\hline Genus & Eggs & Larvae & Pupae & Adults & Water \\
\hline Achromobacter & & & & C61 C64 & \\
\hline Acinetobacter & Ovo9 Ovo14 & $\begin{array}{l}\text { Lar11 C41 Lar3 Lar6 } \\
\text { Lar15 Lar19 Lar27 }\end{array}$ & Pup5 Pup14 Pup19 & $\begin{array}{l}\text { Adu2 Adu22 Adu29 } \\
\text { Adu6 Adu16 Adu21 } \\
\text { Adu44 Adu48 Adu36 }\end{array}$ & $\begin{array}{l}\text { Wat25 Wat1 Wat3 Wat5 } \\
\text { Wat15 Wat21 Wat27 }\end{array}$ \\
\hline Aeromonas & & & Pup4 & Adu13 & \\
\hline Aquitalea & Ovo19 & & & Adu45 & \\
\hline Arthrobacter & & & & Adu34 & \\
\hline Azospirillum & & & Pup15 & & \\
\hline Bacillus & Ovo20 Ovo5 Ovo11 & $\begin{array}{l}\text { Lar1 Lar2 Lar22 C39 } \\
\quad \text { Lar28 }\end{array}$ & $\begin{array}{l}\text { Pup2 Pup10 Pup1 } \\
\text { Pup22 C21 Pup7 } \\
\text { C45 }\end{array}$ & $\begin{array}{l}\text { C55 Adu39 Adu11 } \\
\text { Adu25 Adu15 Adu43 } \\
\text { Adu27 C } 46\end{array}$ & $\begin{array}{c}\text { C14 C4 C67 Wat10 Wat30 } \\
\text { Wat29 Wat18 C2 C22 }\end{array}$ \\
\hline Brevibacterium & & Lar20 & & & \\
\hline Burkholderia & & Lar10 & & & \\
\hline Chromobacterium & & Lar4 Lar7 & Pup6 & $\begin{array}{l}\text { Adu7 Adu23 Adu1 } \\
\text { Adu18 Adu28 Adu26 } \\
\text { Adu37 }\end{array}$ & $\begin{array}{l}\text { Wat4 Wat } 16 \text { Wat26 Wat12 } \\
\text { Wat20 Wat22 }\end{array}$ \\
\hline Citrobacter & Ovo1 & & & & \\
\hline Cronobacter & & Lar26 & & & \\
\hline Cupriavidus & Ovo6 & & & Adu8 Adu17 & Wat34 \\
\hline Elizabethkingia & Ovo12 & Lar21 & & Adu12 Adu42 & \\
\hline Enterobacter ${ }^{* * *}$ & Ovo2 & Lar9 Lar16 Lar12 Lar24 & Pup17 & $\frac{\text { Adu24 Adu30 Adu49 }}{\text { Adu20 }}$ & Wat6 Wat19 Wat13 Wat7 \\
\hline Exiguobacterium & & & Pup16 & & \\
\hline Flectobacillus & & & Pup3 & & \\
\hline Herbaspirillum & & & & Adu31 & \\
\hline Klebsiella & Ovo7 & Lar5 Lar25 & Pup18 Pup20 & Adu14 Adu47 Adu35 & $\begin{array}{l}\text { C30 Wat8 Wat14 Wat24 } \\
\text { Wat33 Wat2 Wat28 }\end{array}$ \\
\hline Leucobacter & & & Pup8 Pup21 & & \\
\hline Lysinibacillus & Ovo16 & & & Adu41 & \\
\hline Microbacterium & Ovo13 Ovo17 & & & Adu19 & \\
\hline Moraxella & Ovo8 & & & Adu9 & \\
\hline Nubsella & & Lar18 & & & \\
\hline Paenibacillus & & Lar8 & & & \\
\hline Pantoea ${ }^{* * *}$ & Ovo3 Ovo15 & Lar13 & Pup12 & Adu3 $\underline{\text { Adu38 }}$ & Wat32 \\
\hline Pectobacterium & & & Pup11 & & \\
\hline Pseudomonas & Ovo10 & Lar17 & & Adu5 Adu46 Adu10 & Wat31 \\
\hline Ralstonia & & & Pup9 & & \\
\hline Rhizobium & & & & & Wat17 \\
\hline Serratia ${ }^{* *}$ & Ovo4 & C19 C36 C37 Lar14 Lar23 & Pup13 Pup23 & C38 C58 $\underline{\text { Adu40 }}$ & C6 C9 Wat9 Wat23 \\
\hline Siccibacter & & & & & C5 C7 C29 \\
\hline Sphingobacterium & Ovo21 & & & & \\
\hline Staphylococcus & & & & Adu33 & \\
\hline Stenotrophomonas & Ovo18 & & & Adu4 Adu32 & Wat11 \\
\hline $\begin{array}{l}35 \text { unique genera of } \\
\text { bacteria }\end{array}$ & 179 Strains & & & & \\
\hline
\end{tabular}

Strains were isolated from larvae, pupae, adult female mosquitoes and breeding site water from Coari (C), or Manaus. Strains from Manaus are isolated from the Anopheles darlingi eggs (Ovo), Larvae (Lar), Pupae (Pup), adult females (Adu) or breeding site surface water (Wat), strains selected for transformation with the plasmid pSPT-1-GFP are indicated with ${ }^{* * *}$ and the strains transformed for additional studies are indicated in bold and underlined. GenBank accession numbers for the $16 \mathrm{~S}$ ribosomal RNA gene sequences are shown in Additional file 1: Tables S1-S5 
in samples from Coari. Serratia and Bacillus were the most common (Additional file 1: Table S1). Samples from Manaus included representatives of Proteobacteria; Firmicutes; Actinobacteria; and Bacteroidetes, distributed in 34 genera. The predominant genera were Bacillus, Acinetobacter, Pseudomonas and Chryseobacterium. Proteobacteria with the largest representation were Acinetobacter, Enterobacter, Klebsiella, Serratia, Pantoea, Stenotrophomonas, and Klebsiella variicola (Additional file 1: Table 2). Firmicutes species were also detected with Bacillus being the most abundant (Additional file 1: Table S3). Three genera of Bacteroidetes were detected with Elizabethkingia (4 strains) being the most abundant (Additional file 1: Table S4). Among four genera of Actinobacteria, Microbacterium and Leucobacter had three and two representative strains, respectively (Additional file 1: Table S5).

\section{Bacterial transformation for paratransgenesis}

Considering the frequency (number of isolated strains) and persistency (findings throughout development) of the identified bacterial strains observed in this study, as well as previous publications on mosquito paratransgenesis, the strains Serratia-Adu40, Enterobacter-Adu24, Pantoea-Adu38, and Pantoea-Ovo3, were selected for further investigation. Serratia and Enterobacter were detected in all developmental stages of An. darlingi as well as in the water of their breeding sites (Table 2). Pantoea species have been successfully applied for paratransgenesis studies in other mosquito species [23, 26]. Those four strains were submitted to electroporation with the plasmid pSPT-1-GFP; however, only SerratiaAdu 40 and Pantoea-Ovo3 were amenable for transformation, as evidenced by producing green fluorescent colonies. To examine recombinant bacteria colonization and survival in the mosquito, female mosquitoes were fed GFP-expressing Serratia and Pantoea and their progeny examined for green fluorescent bacteria. Eggs, larvae, pupae and the next generation of adults were homogenized, and homogenates were plated on selective ampicillin-containing NA medium. For both mosquito groups fed GFP-Serratia and GFP-Pantoea, GFP-expressing bacteria were present in all individuals and developmental stages examined (Fig. 2). Similar results were obtained when F1 mosquitoes were maintained in the presence or absence of ampicillin. The 16S rRNA genes of GFPexpressing bacteria isolated from F1 mosquitoes (GenBank accession numbers MT102128 Serratia-Sm1 and MT102127 Pantoea-Pa1) are identical to those of the original Serratia-Adu40 and Pantoea-Ovo3 strains, indicating there was no horizontal transfer of the plasmid to other bacteria.

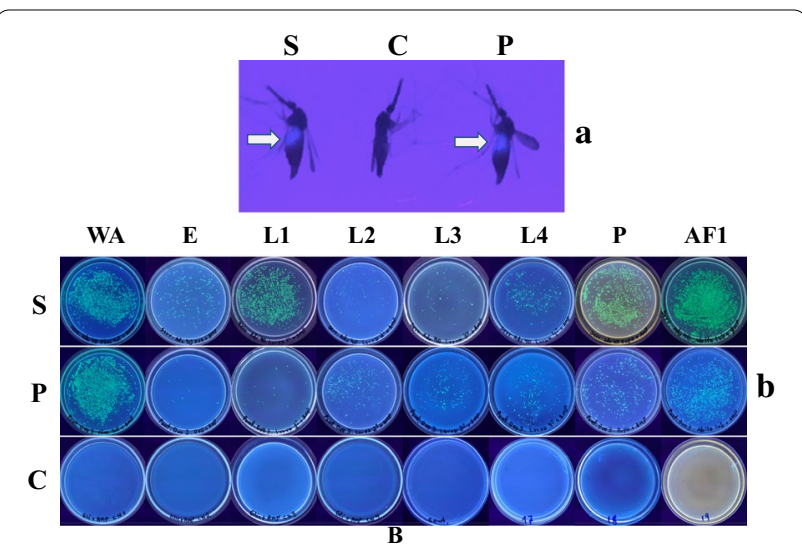

Fig. 2 a Representative samples of fluorescent bacteria-fed mosquitoes. Adult female An. darlingi fed fluorescent bacteria Serratia-Adu40 (S) or Pantoea-Ovo3 (P), and control females not fed fluorescent bacteria (C). White arrows indicate fluorescent abdomen. b Fluorescent bacteria extracted from Wild females (WA) previously fed Serratia-Adu40 (S) or Pantoea-Ovo3 (P), and their progeny; eggs (E), Larvae 1st-4th instars (L1-L4), Pupae (P), and adult female F1 (A F1), in NA plates containing ampicillin. All experiments were conducted in triplicate with 10 eggs, 10 larvae, 10 pupae and 10 adult mosquitoes examined in each replicate. Each larvae, pupae, adult or eggs pool sample was homogenized in $1 \mathrm{ml}$ sterile water and centrifuged for $3 \mathrm{~min}$ at 8,000 rpm. The pellet was resuspended in $200 \mu \mathrm{l}$ of sterile water by vortexing and centrifuged again for $1 \mathrm{~min}$ at $800 \mathrm{rpm}$. From the supernatant, $50 \mu \mathrm{l}$ were plated in each Petri dish. Fluorescent bacteria were detected in $100 \%$ of experimental samples analyzed and were never detected in control plates

\section{Discussion}

Identification of bacteria associated with vector mosquitoes has received particular attention since studies suggest that the vector gut microbiota affects the outcome of mosquito infection with Plasmodium parasites [44-46]. Additionally, paratransgenesis has been proposed as an alternative and supplemental approach for controlling malaria transmission by mosquitoes [21]. Paratransgenesis is based on the use of symbiotic bacteria to express anti-pathogen effector molecules inside the target vector species. For this approach, symbiotic bacteria are isolated, genetically modified to express anti-Plasmodium effector molecules, and then reintroduced into the mosquito, where they produce the desired effect $[25,26]$. Therefore, ideal candidates for paratransgenesis are those easily manipulated genetically, which colonize mosquitoes efficiently, spreading into mosquito populations and are efficient in inhibiting pathogen development in mosquitoes [23].

Although studies have been carried out to identify the bacterial microbiota of malaria vector mosquitoes [30, 47-52], several important vector species remain un-studied or with limited information. Among those is An. darlingi, and other malaria vectors in the American 
continent. Here, the repertoire of culturable bacteria associated with An. darlingi was expanded and investigated for the potential for paratransgenesis. The predominant bacteria genera found associated with $A n$. darling $i$ in this study, in decrescent number of isolated strains, were Bacillus, Acinetobacter, Chromobacterium, Klebsiella, Serratia, and Enterobacter. Other bacteria not amenable for isolation under our protocol likely complement the set of An. darlingi associated microorganisms. Some of those may be candidates for paratransgenesis in this mosquito species. For example, Asaia sp. was found associated with by Oliveira et al. [36] after amplification and sequencing of the $\mathrm{V} 4$ hypervariable region of the $16 \mathrm{~S}$ rRNA. The ability of Asaia to colonize different species of malaria vectors and its demonstrated vertical and transstadial diffusion mechanisms have indicated its potential in paratransgenesis [29].

Colonies of Acinetobacter, Bacillus, Enterobacter, Klebsiella, Pantoea and Serratia were identified in samples extracted from all developmental stages of the mosquito and in their breeding sites, indicative of a strong association between these bacteria and An. darlingi. Acinetobacter and Klebsiella contain species which are potentially pathogenic [53, 54].

Pantoea agglomerans has been found in association with anopheline mosquitoes [31, 55]. Furthermore, Wang et al. [26] engineered $P$. agglomerans to secrete anti-malarial proteins in the mosquito midgut. Mosquitoes carrying these modified bacteria had a significant reduced infection prevalence and showed up to $98 \%$ inhibition of oocyst formation in mosquitoes fed an infectious meal.

Genetic transformation of four strains, Serratia-Adu40, Enterobacter-Adu24, Pantoea-Adu38, and PantoeaOvo3, was attempted with a plasmid that induces the expression of GFP, for the purpose of tracking bacteria transfer among mosquito developmental stages. However, successful identification of green fluorescent bacterial colonies was only achieved with Serratia-Adu40 and Pantoea-Ovo3. Additional effort for the transformation of mosquito-associated bacteria may include the optimization of methods for preparing transformation competent cells and the inclusion of other plasmids carrying different origins of replication and/or marker genes.

Mosquitoes were fed sugar meals containing either Serratia-GFP or Pantoea-GFP to examine recombinant bacteria colonization and survival in An. darlingi mosquitoes. Midguts of female mosquitoes that were fed GFPtagged bacteria became strongly fluorescent, indicating that they were established and multiplying. Transstadial transfer of bacteria in An. darlingi was also investigated. Under the experimental conditions applied in this study, Serratia-GFP or Pantoea-GFP were transferred from gravid females to their eggs, persisted in the hatched larvae throughout all four instars, and remained for the duration of metamorphosis, to be detected in adults of the next generation. It is not clear how viable bacteria remained in eggs after surface-rinsing with $70 \%$ ethanol, since it has been demonstrated that vertical transmission occurs mostly by egg-smearing [56]. Possible contamination of eggs and other specimens following ethanol sterilization has been demonstrated previously and alternative methods of sterilization should be considered in future work [57, 58]. A significant number of bacteria was observed in pupae (Fig. 2), a surprising observation since an effective gut sterilization mechanism operating during mosquito metamorphosis has been reported [59]. Further investigation is needed to clarify these findings; however, whatever route of transmission occurred, vertical transmission was observed in this study.

Taken together, the results reported here indicate that it is possible to introduce genetically transformed bacteria in An. darlingi females by a sugar meal, that the bacteria may survive, multiply and express a GFP marker (eventually an anti-Plasmodium effector molecule), and that Serratia-Adu40 and Pantoea-Ovo3 are transferred from adult females to their eggs, from eggs to larvae and finally to adults in the next generation. Vertical transmission of Serratia sp. in Anopheles and Pantoea sp. in Culex mosquitoes has been demonstrated previously [60, 61].

Additional research is needed to determine if these bacteria are also vertically transferred in nature. Furthermore, careful studies need to be performed certifying that these isolated strains do not carry virulent genes causing pathologic conditions in humans, animals or plants.

While paratransgenesis technical tools may be available, implementing an effective and scalable paratransgenesis-based malaria control strategy is still in the conceptual stage. Issues related to efficacy and biosafety need to be addressed and a regulatory framework for this specific application needs to be established. However, inaction should not be the option. The potential public health benefit of new tools to reduce or even eradicate malaria is clear and widely recognized. The risks incurred by testing new, and unproven strategies and the risks to human health and the environment posed by maintaining the status quo should be taken into account in decision-making.

\section{Supplementary Information}

The online version contains supplementary material available at https://doi. org/10.1186/s12936-020-03574-1.

Additional file 1: Table S1. Bacteria isolated from samples from Coari. Table S2. Proteobacteria isolated from samples from Manaus. Table S3. 
Firmicutes isolated from samples from Manaus. Table S4. Bacteroidetes isolated from samples from Manaus. Table S5. Actinobacteria isolated from samples from Manaus.

\section{Acknowledgements}

We thank the Graduate Program in Biotechnology_-PPGBIOTEC / UFAM and the National Institute for Research in the Amazon-INPA. We thank Enedina Nogueira de Assunção, Paulo Abraão Cavalcante Maranhão, Leissandra Nascimento Castelo, Kerollen Runa Pinto, Júlio Nino de Souza Neto, Diego da Silva Moreira and Simone Cardoso Soares for the general support in the laboratory, as well as Rejane de Castro Simões and Francisco Augusto da Silva Ferreira for their help in collecting and the maintenance of mosquitoes included in this study. Jayme A. Souza-Neto was a São Paulo Research Foundation (FAPESP) Young Investigator (Grant Number 2013/11343-6)

\section{Authors' contributions}

Designed the study-EMR, OM, OT, RMK and WPT. Collected the samples and performed the bacterial isolations-EMR, RMK, DMS, LVC, JCO, VAM and MRO. Performed the molecular procedures (PCR and Sanger Sequencing) - EMR, RMK, JFNN, MCFP, AJM and PO. Analysed the results and wrote the manuscript-EMR, OM, MCFP, RAR, WPT, JASN and OT. Supervised and finalized the manuscript-EMR, OM, RMK, MCFP, RAR, JASN, OT and WPT. All authors read and approved the final manuscript.

\section{Funding}

Open Access funding provided by Uppsala University. Open Access funding provided by Uppsala University. This study was financed in part by the Coordenação de Aperfeiçoamento de Pessoal de Nível Superior-Brasil (CAPES) - Finance Code 001, by the Swedish Research Council (Grant Number 348-2012-622), by the project Pró-Amazônia: Biodiversidade e Sustentabilidade (process number 23038.009442/2013-12) and by the Programa de Apoio à Fixação de Doutores no Amazonas_FIXAM/FAPEAM (Process Number 062.02805/2015).

\section{Availability of data and materials}

All data generated or analysed during this study are included in this published article and its supplementary information files. DNA sequences are available at National Center for Biotechnology Information http://www.ncbi.nlm.nih.gov.

\section{Ethics approval and consent to participate}

The Sistema de Autorização e Informação em Biodiversidade-SISBIO, authorized the collection of mosquitoes (immature and adult) (Number 17524-1) and the maintenance of mosquitoes in laboratory in accordance with ethical standards (Number 21264-5). All sequences were registered in SisGen database, Brazil (Sistema Nacional de Gestão do Patrimônio Genético e do Conhecimento Tradicional Associado) with the number A0F653E.

\section{Consent for publication}

Not applicable.

\section{Competing interests}

The authors declare that they have no competing interests.

\section{Author details}

${ }^{1}$ Programa de Pós-Graduação em Biotecnologia, Universidade Federal do Amazonas - PPGBIOTEC / UFAM, Manaus, Brazil. ${ }^{2}$ MTEKPrime, Aliso Viejo, CA, USA. ${ }^{3}$ Universidade Estadual do Amazonas - MBT, UEA, Manaus, Brazil. ${ }^{4}$ Universidade Estadual do Amazonas - BIONORTE, UEA, Manaus, Brazil. ${ }^{5}$ Laboratório de Malária E Dengue, Instituto Nacional de Pesquisas da Amazônia, INPA, Manaus, Brazil. ${ }^{6}$ Department of Ecology, Swedish University of Agricultural Sciences (SLU), Box 7044, 75007 Uppsala, Sweden. ${ }^{7}$ School of Agricultural Sciences, Department of Bioprocesses and Biotechnology, Central Multi User Laboratory, São Paulo State University (UNESP), Botucatu, Brazil. ${ }^{8}$ Department of Cell and Molecular Biology, Microbiology, Uppsala University, Box 596, 75124 Uppsala, Sweden.

Received: 19 August 2020 Accepted: 29 December 2020 Published online: 13 January 2021

\section{References}

1. WHO. World malaria report. Geneva: World Health Organization; 2019. https://www.who.int/publications-detail-redirect/9789241565721

2. Jaramillo-Ochoa R, Sippy R, Farrell DF, Cueva-Aponte C, Beltrán-Ayala E, Gonzaga JL, et al. Effects of political instability in Venezuela on malaria resurgence at Ecuador-Peru Border, 2018. Emerg Infect Dis. 2019;25:834-6.

3. Tadei WP, Rodrigues IB, Rafael MS, Sampaio RTM, Mesquita HG, Pinheiro VCS, et al. Adaptative processes, control measures, genetic background, and resilience of malaria vectors and environmental changes in the Amazon region. Hydrobiologia. 2017;789:179-96.

4. Carlos BC, Rona LDP, Christophides GK, Souza-Neto JA. A comprehensive analysis of malaria transmission in Brazil. Pathog Glob Health. 2019;113:1-13.

5. Charlwood JD. Biological variation in Anopheles darlingi Root. Mem Inst Oswaldo Cruz. 1996;91:391-8.

6. Vittor AY, Gilman RH, Tielsch J, Glass G, Shields T, Lozano WS, et al. The effect of deforestation on the human-biting rate of Anopheles darlingi, the primary vector of falciparum malaria in the Peruvian Amazon. Am J Trop Med Hyg. 2006;74:3-11.

7. Hiwat H, Bretas G. Ecology of Anopheles darlingi Root with respect to vector importance: a review. Parasit Vectors. 2011;4:177.

8. Tadei WP, Thatcher BD, Santos JM, Scarpassa VM, Rodrigues IB, Rafael MS. Ecologic observations on anopheline vectors of malaria in the Brazilian Amazon. Am J Trop Med Hyg. 1998;59:325-35.

9. Marrelli MT, Honório NA, Flores-Mendoza C, Lourenco-de-Oliveira R, Marinotti O, Kloetzel JK. Comparative susceptibility of two members of the Anopheles oswaldoi complex, An. oswaldoi and An. konderi, to infection by Plasmodium vivax. Trans R Soc Trop Med Hyg. 1999;93:381-4.

10. Okuda K, Caroci A, Ribolla P, Marinotti O, de Bianchi AG, Bijovsky AT. Morphological and enzymatic analysis of the midgut of Anopheles darlingi during blood digestion. J Insect Physiol. 2005;51:769-76.

11. Scarpassa VM, Conn JE. Population genetic structure of the major malaria vector Anopheles darlingi (Diptera: Culicidae) from the Brazilian Amazon, using microsatellite markers. Mem Inst Oswaldo Cruz. 2007;102:319-28.

12. Mirabello L, Vineis JH, Yanoviak SP, Scarpassa VM, Póvoa MM, Padilla N, et al. Microsatellite data suggest significant population structure and differentiation within the malaria vector Anopheles darlingi in Central and South America. BMC Ecol. 2008;8:3.

13 Marinotti O, Cerqueira GC, de Almeida LGP, Ferro MIT, da Loreto ELS, Zaha A, et al. The genome of Anopheles darlingi, the main neotropical malaria vector. Nucleic Acids Res. 2013;41:7387-400.

14. Zamora Perea E, Balta León R, Palomino Salcedo M, Brogdon WG, Devine GJ. Adaptation and evaluation of the bottle assay for monitoring insecticide resistance in disease vector mosquitoes in the Peruvian Amazon. Malar J. 2009:8:208.

15. Kobylinski KC, Escobedo-Vargas KS, López-Sifuentes VM, Durand S, Smith ES, Baldeviano GC, et al. Ivermectin susceptibility, sporontocidal effect, and inhibition of time to re-feed in the Amazonian malaria vector Anopheles darlingi. Malar J. 2017;16:474.

16. Rocha EM, de Katak RM, Campos de Oliveira J, da Araujo MS, Carlos BC, Galizi R, et al. Vector-focused approaches to curb malaria transmission in the Brazilian Amazon: an overview of current and future challenges and strategies. Trop Med Infect Dis. 2020;5:161.

17. Conn JE, Ribolla PE. Chapter 5-Ecology of Anopheles darlingi, the primary malaria vector in the Americas and current nongenetic methods of vector control. In: Adelman ZN, editor. Genetic Control of Malaria and Dengue. Boston: Academic Press; 2016. p. 81-102.

18. Baia-da-Silva DC, Brito-Sousa JD, Rodovalho SR, Peterka C, Moresco G, Lapouble OMM, et al. Current vector control challenges in the fight against malaria in Brazil. Rev Soc Bras Med Trop. 2019;52:e0007615.

19. Terenius $O$, Marinotti $O$, Sieglaff $D$, James AA. Molecular genetic manipulation of vector mosquitoes. Cell Host Microbe. 2008;4:417-23.

20. Carballar-Lejarazú R, James AA. Population modification of Anopheline species to control malaria transmission. Pathog Glob Health. 2017;111:424-35.

21. Wilke ABB, Marrelli MT. Paratransgenesis: a promising new strategy for mosquito vector control. Parasit Vectors. 2015;8:342.

22. Li J, Han M, Yu J. Simple paratransgenic mosquitoes models and their dynamics. Math Biosci. 2018;306:20-31.

23. Huang W, Wang S, Jacobs-Lorena M. Use of microbiota to fight mosquitoborne disease. Front Genet. 2020;11:196. 
24 Asgari M, Ilbeigikhamsehnejad M, Rismani E, Dinparast Djadid N, Raz A. Molecular characterization of RNase III protein of Asaia sp. for developing a robust RNAi-based paratransgensis tool to affect the sexual life-cycle of Plasmodium or Anopheles fitness. Parasit Vectors. 2020;13:42.

25. Yoshida S, loka D, Matsuoka H, Endo H, Ishii A. Bacteria expressing singlechain immunotoxin inhibit malaria parasite development in mosquitoes. Mol Biochem Parasitol. 2001;113:89-96.

26 Wang S, Ghosh AK, Bongio N, Stebbings KA, Lampe DJ, Jacobs-Lorena M. Fighting malaria with engineered symbiotic bacteria from vector mosquitoes. Proc Natl Acad Sci USA. 2012;109:12734-9.

27. Wang S, Dos-Santos ALA, Huang W, Liu KC, Oshaghi MA, Wei G, et al. Driving mosquito refractoriness to Plasmodium falciparum with engineered symbiotic bacteria. Science. 2017;357:1399-402.

28. Villegas LM, Pimenta PFP, Villegas LM, Pimenta PFP. Metagenomics, paratransgenesis and the Anopheles microbiome: a portrait of the geographical distribution of the anopheline microbiota based on a meta-analysis of reported taxa. Mem Inst Oswaldo Cruz. 2014;109:672-84.

29. Mancini MV, Spaccapelo R, Damiani C, Accoti A, Tallarita M, Petraglia E, et al. Paratransgenesis to control malaria vectors: a semi-field pilot study. Parasit Vectors. 2016;9:140.

30. Raharimalala FN, Boukraa S, Bawin T, Boyer S, Francis F. Molecular detection of six (endo-) symbiotic bacteria in Belgian mosquitoes: first step towards the selection of appropriate paratransgenesis candidates. Parasitol Res. 2016;115:1391-9.

31. Terenius $O$, de Oliveira CD, Pinheiro WD, Tadei WP, James AA, Marinotti O. $16 \mathrm{~S}$ rRNA gene sequences from bacteria associated with adult Anopheles darlingi (Diptera: Culicidae) mosquitoes. J Med Entomol. 2008;45:172-5.

32 Kämpfer P, Glaeser SP, Marinotti O, Guy L, Håkansson S, Tadei WP, et al. Coetzeea brasiliensis gen. nov., sp. nov. isolated from larvae of Anopheles darlingi. Int J Syst Evol Microbiol. 2016;66:5211-7.

33 Arruda A, Ferreira GS, da Lima NCS, dos Santos Júnior A, Custódio MGF, Benevides-Matos N, et al. A simple methodology to collect culturable bacteria from feces of Anopheles darlingi (Diptera: Culicidae). J Microbiol Methods. 2017;141:115-7

34. Nilsson LKJ, de Oliveira MR, Marinotti O, Rocha EM, Håkansson S, Tadei WP, et al. Characterization of bacterial communities in breeding waters of Anopheles darlingi in Manaus in the Amazon Basin malaria-endemic area. Microb Ecol. 2019;78:781-91.

35. Oliveira TMP, Sanabani SS, Sallum MAM. Bacterial diversity associated with the abdomens of naturally Plasmodium-infected and non-infected Nyssorhynchus darlingi. BMC Microbiol. 2020;20:180.

36. Oliveira TMP, Sanabani SS, Sallum MAM. Asaia (Rhodospirillales: Acetobacteraceae) and Serratia (Enterobacterales: Yersiniaceae) associated with Nyssorhynchus braziliensis and Nyssorhynchus darlingi (Diptera: Culicidae). Rev Bras Entomol. 2020;64:1-4.

37. Agogué $\mathrm{H}$, Casamayor EO, Joux F, Obernosterer I, Dupuy C, Lantoine $F$, et al. Comparison of samplers for the biological characterization of the sea surface microlayer. Limnol Oceanogr Methods. 2004;2:213-25.

38. Service MW. Mosquito ecology field sampling methods. London: Elsevier; 1993.

39. Consoli RAGB, Oliveira RL de. Principais mosquitos de importância sanitária no Brasil. Editora FIOCRUZ; 1994.

40. Fukatsu T, Nikoh N. Two intracellular symbiotic Bacteria from the Mulberry Psyllid Anomoneura mori (Insecta, Homoptera). Appl Environ Microbiol. 1998:64:3599-606

41. Sawada H, leki H, Oyaizu H, Matsumoto S. Proposal for rejection of Agrobacterium tumefaciens and revised descriptions for the Genus Agrobacterium and for Agrobacterium radiobacter and Agrobacterium rhizogenes. Int J Syst Evol Microbiol. 1993;43:694-702.

42. Huang X, Madan A. CAP3: a DNA sequence assembly program. Genome Res. 1999;9:868-77.

43. Gonzales MF, Brooks T, Pukatzki SU, Provenzano D. Rapid protocol for preparation of electrocompetent Escherichia coli and Vibrio cholerae. J Vis Exp. 2013;80:e50684.

44. Pumpuni CB, Beier MS, Nataro JP, Guers LD, Davis JR. Plasmodium falciparum: Inhibition of sporogonic development in Anopheles stephensi by Gramnegative bacteria. Exp Parasitol. 1993;77:195-9.
45. Dong Y, Manfredini F, Dimopoulos G. Implication of the mosquito midgut microbiota in the defense against malaria parasites. PLoS Pathog. 2009;5:e1000423.

46. Gendrin M, Christophides GK. The Anopheles mosquito microbiota and their impact on pathogen transmission. In: Anopheles Mosquitoes-New Insights Malar Vectors. Manguin S, Ed. IntechOpen; 2013. https://www.intechopen .com/books/anopheles-mosquitoes-new-insights-into-malaria-vectors/ the-anopheles-mosquito-microbiota-and-their-impact-on-pathogen-trans mission.

47. Boissière A, Tchioffo MT, Bachar D, Abate L, Marie A, Nsango SE, et al. Midgut microbiota of the malaria mosquito vector Anopheles gambiae and interactions with Plasmodium falciparum infection. PLoS Pathog. 2012;8:e1002742.

48. Chavshin AR, Oshaghi MA, Vatandoost H, Pourmand MR, Raeisi A, Terenius O. Isolation and identification of culturable bacteria from wild Anopheles culicifacies, a first step in a paratransgenesis approach. Parasit Vectors. 2014;7:419.

49. Ngo CT, Romano-Bertrand S, Manguin S, Jumas-Bilak E. Diversity of the bacterial microbiota of Anopheles mosquitoes from Binh Phuoc Province. Vietnam Front Microbiol. 2016;7:2095.

50. Rami A, Raz A, Zakeri S, Dinparast DN. Isolation and identification of Asaia sp. in Anopheles spp. mosquitoes collected from Iranian malaria settings: steps toward applying paratransgenic tools against malaria. Parasit Vectors. 2018;11:367.

51. Galeano-Castañeda Y, Urrea-Aguirre P, Piedrahita S, Bascuñán P, Correa MM. Composition and structure of the culturable gut bacterial communities in Anopheles albimanus from Colombia. PLoS ONE. 2019;14:e0225833.

52. Berhanu A, Abera A, Nega D, Mekasha S, Fentaw S, Assefa A, et al. Isolation and identification of microflora from the midgut and salivary glands of Anopheles species in malaria endemic areas of Ethiopia. BMC Microbiol. 2019;19:85.

53. Seibert G, Hörner R, Meneghetti BH, Righi RA, Forno NLFD, Salla A, et al. Nosocomial infections by Klebsiella pneumoniae carbapenemase producing enterobacteria in a teaching hospital. Einstein São Paulo. Instituto Israelita de Ensino e Pesquisa Albert Einstein; 2014;12:282-6.

54. Subhadra B, Surendran S, Lim BR, Yim J-S, Kim DH, Woo K, et al. Complete genome sequence and phylogenetic analysis of nosocomial pathogen Acinetobacter nosocomialis strain NCTC 8102. Genes Genomics. 2019;41:1063-75.

55. Rani A, Sharma A, Rajagopal R, AdakT, Bhatnagar RK. Bacterial diversity analysis of larvae and adult midgut microflora using culture-dependent and culture-independent methods in lab-reared and field-collected Anopheles stephensi-an Asian malarial vector. BMC Microbiol. 2009;9:96.

56. Crotti E, Rizzi A, Chouaia B, Ricci I, Favia G, Alma A, et al. Acetic acid bacteria, newly emerging symbionts of insects. Appl Environ Microbiol. 2010;76:6963-70.

57. Binetruy F, Dupraz M, Buysse M, Duron O. Surface sterilization methods impact measures of internal microbial diversity in ticks. Parasit Vectors. 2019;12:268.

58. Ribeiro MM, Neumann VA, Padoveze MC, Graziano KU, et al. Eficacia y efectividad del alcohol en la desinfección de materiales semicríticos: revisión sistemática. Rev Lat Am Enfermagem. 2015;23:741-52.

59. Moll RM, Romoser WS, Modrakowski MC, Moncayo AC, Lerdthusnee K. Meconial peritrophic membranes and the fate of midgut bacteria during mosquito (Diptera: Culicidae) metamorphosis. J Med Entomol. 2001;38:29-32.

60. Cifelli AN. Horizontal and vertical transmission of a Pantoea Sp. in Culex Sp. [Thesis]. 2015. http://dspace.calstate.edu/handle/10211.3/196892.

61. Koosha M, Vatandoost H, Karimian F, Choubdar N, Oshaghi MA. Delivery of a genetically marked Serratia AS1 to medically important arthropods for use in RNAi and paratransgenic control strategies. Microb Ecol. 2019;78:185-94.

\section{Publisher's Note}

Springer Nature remains neutral with regard to jurisdictional claims in published maps and institutional affiliations. 